\title{
3. 医薬品開発におけるリアルワールドデータ活用 への期待 一製薬企業の視点より一
}

\author{
東郷 香苗 ${ }^{* 1, * 2}$, 川松 真也 ${ }^{* 1, * 3}$, 木口 亮 ${ }^{* 1, * 4}$, 今井 康彦 $* 1, * 5$ \\ *1 日本製薬工業協会 医薬品評価委員会 臨床評価部会 \\ *2 ファイザー株式会社 \\ *3 グラクソ・スミスクライン株式会社 \\ *4 塩野義製薬株式会社 \\ *5 ブリストル・マイヤーズスクイブ株式会社
}

\begin{abstract}
〈抄録〉医薬品開発に扔けるエビデンス創出はこれまで臨床試験に偏っていたが，そのア プローチにはもっと選択肢があるべきであり,リアルワールドデー夕（RWD）がその役割 を果たすことが期待される，ICH GCPリノベーションでも，多様な試験デザインとデー タソースの選択肢を持つこと, 患者に画期的な新薬を早く提供するために早期承認申請を サポートすることが挙げられている。本邦に扔いても，条件付き早期承認制度や改正 GPSP 省令で医療情報データベースや患者レジストリ等の活用が可能であることが明記さ れた。本稿では，医薬品開発に扔ける RWDの活用として，(1) 承認申請データへの活用， (2) 臨床試験計画㧍よび患者リクルートメントへの活用, (3) Electronic Health Record を データソースとした臨床試験データの収集, (4) 臨床試験の評価や診断への活用, (5) 開発戦 略, 薬価・アクセス戦略への活用についてまとめる。 それぞれの活用場面で課題があり, インフラと規制環境の整備が望まれるものの, それを待つことなく医薬品開発の現場で RWDの活用が進むことに期待したい.

(薬剂度学 2019；24(1)：19-30) キーワード：リアルワールドデータ, リアルワールドエビデンス
\end{abstract}

\section{1.はじめに}

デジタル技術の革新により多くのリアルワール ドデータ (RWD) が電子的に蓄積され, 情報通信 技術（ICT）の向上によりさまざまなデータソー スへのアクセスが可能となった. 電子商取引, 自 動車産業, ヘルスケアなどさまざまな分野でビッ グデータ・RWDの活用は進んでいるものの, 医 薬品開発において同じ速さで活用が進んでいると は言い難い. 医薬品開発が抱える次のような課題 を考えると， RWD はもっと活用されるべきであ
る。まず, 臨床試験の観点からは, 侵襲を伴う場 合や，無作為化試験では患者は投与群を選択でき ない, 通常診療以上の検査が必要になるなど, 患 者や医療関係者の多くの協力によって成り立って いる. 次に, 製薬企業の立場からは, 希少疾患や 希少フラグメント, 再生医療や遺伝子治療など, 従来の枠組みでは対応できない開発が増えてい る. 加えて, 医薬品の開発コストが高騰し, かつ, 国民医療費の高騰による薬価制度の改革により国 内市場の予見性が低くなり, 製薬企業にとって医

著者連絡先: ₹ 151-8589 東京都渋谷区代々木 3-22-7 新宿文化クイントビル ファイザー株式会社コーポレー トアフェアーズ ヘルス\&バリュー 東郷香苗

TEL : 080-4613-2753 E-mail : kanae.togo@pfizer.com 
薬品開発のリスクは高まっている。ささらに, 臨床 試験から得られるデータは限局的である一方で, 市販後の安全性監視活動の重要性の高まり，医療 技術評価の導入予定，患者中心の医療など，製薬 企業は承認申請以外でもより多様な目的でデー夕 創出が必要となっている.

このような状況下で, 医薬品開発における RWD の活用を進めることで, 不必要な介入や負 担をなくし，開発コストを削減し，包括的なデー 夕創出を目指すことは必然であろう。勿論 RWD が無作為化試験の完全な代替になるわけではな い. 無作為化試験は, 観察された交絡因子だけで なく, 観察されていない交絡因子でも偶然起こり うる不均衡以上の偏りは生じないため, 妥当な比 較を行うための最も強力な方法である。一方, RWD における交絡を調整する手法はあるもの の, 未測定の交絡因子が存在しない等の強い仮定 の下にある. それでも, 医薬品開発におけるデー 夕創出のアプローチにはもっと選択肢があるべき であり，RWD がその役割を果たすＩCH GCP リ ノベーションでも, 多様な試験デザインとデー夕 ソースの選択肢を持つこと, 患者に画期的な新薬 を早く提供するために早期承認申請をサポートす ることが挙げられている1).

本邦では, 条件付き早期承認制度が 2017 年に 施行され, 承認条件として製造販売後に必要とな る有効性・安全性のための調査等に, 医療情報デー タベースや患者レジストリ等を活用可能であるこ とが明記された ${ }^{2)}$ 。また, 2018 年に施行された改 正 GPSP 省令では，医療情報データベースを利用 した製造販売後データベース調査が可能となって いる ${ }^{3)}$. 患者レジストリの活用の枠組みとして は, 国立高度専門医療研究センターを中心とした クリニカル・イノベーション・ネットワークがあ る。また, 日本医療研究開発機構 (AMED) 林班 による「患者レジストリデータを医薬品等の承認 申請資料等として活用する場合におけるデータの 信頼性担保に関する基本的考え方 (案)」も検討さ れた ${ }^{4)}$. 医療ビッグデータに関する政策では, 健 康・医療戦略に医療等デー夕利活用基盤構築・ ICT 利活用推進に関する施策が盛り込まれ ${ }^{5)}$, そ
こから 2017 年の「医療分野の研究開発に資する ための匿名加工医療情報に関する法律（次世代医 療基盤法)」の公布に至った ${ }^{6)}$. また, 厚生労働省 のデータヘルス改革推進計画では, 2020 年以降に 健康・医療・介護のビッグデータを「医療等 ID」 で連結しプラットフォーム化すること, 治験・臨 床研究への患者アクセスの向上や新たな治療法の 開発や創薬の加速などが挙げられている7

米国では, 2016 年に成立した 21st Century Cures Act で新薬開発, 効能追加および市販後安 全性におけるリアルワールドエビデンス（RWE） の利活用を挙げた ${ }^{8)}$. 本法の下でFDA は 2021 年 にガイドライン化を目指して動いており，FDA と製薬企業のワークショップなど，業界とのコ ミュニケーションも積極的に行われている. ま た, FDA は既に医療機器の RWEに関するガイ ダンスを出している . 欧州は Innovative Medicines Initiative（IMI）の GetREAL プロジェクト で，RWEを医薬品開発に活用する取り組みを産 官で行っている ${ }^{10)}$.

本稿では，医薬品開発における RWDの活用と して, (1) 承認申請データへの活用, (2) 臨床試験計 画および患者リクルートメントへの活用, (3) Electronic Health Record（EHR）をデータソース とした臨床試験データの収集, (4) 臨床試験の評価 や診断への活用, (5) 開発戦略, 薬価・アクセス戦 略への活用についてまとめる。また，それぞれの 活用場面における課題について述べる. なお, 本 稿ではRWD を ISPOR-ISPE タスクフォースによ る，無作為化比較試験以外の日常診療下で生成さ れるデー夕と定義する ${ }^{11)}$. RWE は，RWD からさ まざまな研究・解析手法を適用して導き出された エビデンスとする.

\section{2. リアルワールドデータの期待される活用場面}

\section{1 承認申請データへの活用}

まず，RWD から得た RWE を承認申請の臨床 データパッケージに直接含める場面を考える. RWE は前述のとおり比較・検証という意味では 無作為化試験以上の強力なエビデンスではない が，それでも新薬の承認申請の活用場面は多いだ 
ろう. 具体的には, 希少疾病領域のような例数確 保が困難な試験や倫理的観点からプラセボ対照群 を設定することが難しい試験などで, 有効性や安 全性の比較のための外部対照として活用したり, 進行を伴う疾患での疾患進行の経過 (natural history）を評価するために活用したりすることが挙 げられる。実際に, FDAの break through therapy 指定を受けた 3 つの薬剤（うち 2 つはがん領 域）が, RWEによる外部対照を活用して単群の 臨床試験で承認を取っている。例えば，ロシュ社 は, 肺がん患者を対象とした単群試験のデータと, Flatiron Health 社の EHR データベースから創出 した仮想対照群との比較を実施した ${ }^{1213)}$. がん領 域等の生存時間など長期観察の必要な評価項目 は, 試験実施の負担や後治療等の影響が大きいた め, RWD を最大限活用することが望まれる.

新薬の承認申請以外でも, 適応追加の申請や, 用法用量の変更, 添付文書改訂等で RWE が活用 されることが期待される.このような場面では, pragmatic clinical trial (PCT) や registry-based randomized clinical trial (RRCT) をより適用しや すいだろう。より日常診療に近い環境での臨床試 験である PCT は多様なデザインがあり ${ }^{14)}$, PCT から得られた結果を RWE と呼ぶかは議論がある だろうが, 事例としてグラクソ・スミスクライン 社が実施した Salford Lung Studyを紹介す $ろ^{15)-19)}$.この Salford Lung Study は, 英国・サル フォードを中心に実施した 2 つ非盲検無作為化 臨床試験を指す。本試験では 60 以上の実施医療 機関の EHR から収集した多様な種類のデー夕に 基づき, 日常診療に近い環境における, 通常治療 と比較したときの薬剤特性という RWEを創出し た。また, RRCTの可能性についても言及した い. 北欧諸国では，医療デー夕を国の政策として 長年にわたり蓄積しており, 例えばスウェーデン では，国民の生活に関係するあらゆる登録台帳を レジスターと総称し, さまざまな用途で登録され たレジスターを公的組織がクリーニングして保管 している ${ }^{20)}$. スウェーデンの施設を中心に実施さ れた RRCT である TASTE 試験では, このレジ スターを活用することで迅速な患者登録と安価な
薬剤疫学 Jpn J Pharmacoepidemiol, 24(1) Jan 2019 : 21

試験実施を実現している ${ }^{21)}$.

しかし，このような RWE を活用した医薬品開 発には課題が多い。一つは研究目的に対する適合 性 (relevancy) の課題である。二次利用データの 場合, 必要とするアウトカムが含まれていない場 合や, 患者集団が研究目的と合わない場合がある. また, 適応追加や用法用量変更の申請に RWEを 活用したい場合に, 保険請求データでは適応外や 用法用量外の RWD を収集できない可能性があ る. 次に, RWD は通常は処置の無作為化が行わ れないため, 交絡因子を調整せずに処置の比較を 行うと重大なバイアスが入る可能性がある ${ }^{22}$. 傾 向スコアによるマッチング等, バイアスを最小化 するための統計的手法はあるものの, 強い仮定を 置いているものが多いため, その仮定が実際に当 てはまるか注意が必要である。そして, 承認申請 の臨床データパッケージとする際の大きな課題は データの質である. 多くの RWD は二次利用デー 夕で, データが発生する状況は一次利用目的に依 存し, データの問合せも通常はできないため, ソー スデータの質の担保が特に課題となる. RWDの 質はプロセスで担保すべきだが，RWDには多様 なデータソースがあり, 個々のデータソースの質 は均一ではなく, また, 例えば希少疾病の数十例 の患者データから数十万の患者デー夕を扱うケー スまであり，個々のデー夕に求める質も異なる. RWEから得られる結論とその結論から行う意思 決定にデータの質が影響を及ぼす範囲を個別に考 える必要がある. Duke University Margolis Center for Health Policy のホワイトペーパーでは, こ のデータの質と適合性に対して取り組むべき点が まとめられている ${ }^{23)}$. 米国のような RWEの利活 用に関するガイダンス発行を視野に, 本邦におい ても国や地方自治体, アカデミアと連携した，よ り活発な議論を期待したい.

\section{2 臨床試験計画および患者リクルートメントへの 活用}

2つ目の RWD の活用場面として, 臨床試験計 画および患者リクルートメントへの活用を取り上 げる。臨床試験の計画および実施は“realistic” である必要がある。この目線が不足していれば, 
表 1 各ソースデータと期待される効果

\begin{tabular}{|c|c|}
\hline ソースデー夕 & 期待される効果 \\
\hline $\begin{array}{l}\text { 検査值データ } \\
\text { 患者レベルの疫学データ }\end{array}$ & $\begin{array}{l}\text { •組み入れ妥当性や組み入れスピードの予測 } \\
\text { ·試験期間中の被験者の病態進行の予測 }\end{array}$ \\
\hline $\begin{array}{l}\text { 薬剂処方記録 } \\
\text { レセプトデータ }\end{array}$ & $\begin{array}{l}\text { ·実情を反映した組み入れ基準や併用薬の検討 } \\
\text { •試験中の服薬コンプライアンスの予測 }{ }^{28)}\end{array}$ \\
\hline 患者や医師 · 学会の意見 ${ }^{29)}$ & $\begin{array}{l}\text { ·無益性やそれに伴う脱落率の予測 } \\
\text { ·被験者の負担にならない来院/検査の頻度・内容などの検討 }\end{array}$ \\
\hline
\end{tabular}

依頼者，実施医療機関および被験者各々が過剩な 負担を被り，被験者組入れや規定の遵守は困難と なる，実際に，被験者組入れを理由に早期中止/ 終了した臨床試験は 19\%, 期間延長した試験は $86 \%$ にも上るという報告もある ${ }^{24)}$. そこで, RWD の活用により臨床試験に実情を反映させる 考え方が広まっており, 中でも盛んに議論されて いるのが, 臨床試験計画および患者リクルートメ ントへの活用である.

試験計画の実現可能性は, 試験計画の骨子の段 階で, 対象疾患の治療ガイドラインや医師の助言 などをもとに検討される。最近では, 数学的手法 を用いた臨床試験シミュレーションの利用も増え ており ${ }^{25)}$ ，このとき患者背景やアウトカムの推移 などの支持デー夕にRWD を活用することで，よ り精度が高く定量的な評価ができる.さらに, 近 年重視されている患者を中心とした臨床試験デザ インの検討に，RWDを反映することにより実施 計画を最適化する試みも進められている26). 各 ソースデータとその期待される効果を表 1 に示 す.

被験者の組入れ段階でも, 現在行われている医 療機関スタッフのマニュアルスクリーニングに加 えて，RWD を用いて実情を適切に把握しながら 組入れを進めるアプローチが取り組まれている.

本邦では, SCRUM-Japanにおける全国 240 施設 4,000 例の肺がん患者の次世代シークエンサー情 報を利活用し, 臨床試験の候補患者を見出した例 がある ${ }^{30)}$. さらに海外では, 電子カルテデータと 製薬企業が登録した臨床試験情報をマッチングす ることで医師に組入れ可能な臨床試験を提案した
り，患者同士の医療情報共有コミュニティサイト に実施中の臨床試験情報を掲載したりする新しい 組入れ促進策も試みられている311. このような RWD を用いた被験者検知方法を確立すること で, 被験者組入れを加速できる.

ただし，このような RWDの活用にはデータの 共有体制のさらなる整備が必要である. 臨床試験 計画や患者リクルートメントで利用する RWD は 実情を再現できることが望ましいが, 現在の日本 のデー夕共有体制はゲノムデータやがん領域に限 られている。 また，レセプト情報・特定健診等情 報データベース（NDB）や診断群分類別包括評価 （DPC）デー夕等, 国の保有する大規模保険デー タベースの二次利用は学術研究機関の研究目的に 限られており, 民間企業の利用への道は遠い。今 後, 次世代医療基盤法の認定匿名加工医療情報作 成事業者の設立が推進されれば，利用可能となる 匿名加工情報並びにデータベース同士のリンケー ジも増えることが期待できる，さらに別の課題と して，RWD から得られる個人情報の取扱いがあ る。例えば，患者リクルートメントでは施設・患 者側に臨床試験情報を提供できても, 製薬企業は 匿名加工情報上では該当患者のいる施設名までは 得られない。 また, 国際同時開発においては国際 的なデー夕共有が必要だが, 海外への情報持ち出 しに関する規制は国によってさまざまであるた め, 規制上の要件を十分理解したうえでデー夕を 活用する必要がある。

\subsection{EHR をデータソースとした臨床試験データの 収集}

臨床試験におけるデータの収集ならびにクリー 
表 2 本邦における EHR の代表例

\begin{tabular}{|c|c|}
\hline EHR & 内容 \\
\hline 千年カルテプロジェクト & $\begin{array}{l}150 \text { 施設の基幹病院の電子カルテ情報を EHR センターに集約することを目指 } \\
\text { している. この集約したデータの二次利用として, 外部への提供も視野に入れ } \\
\text { ており, 臨床試験への活用も期待される }{ }^{35)} \text {. }\end{array}$ \\
\hline $\begin{array}{l}\text { 大阪臨床研究ネット } \\
\text { ワーク（OCR-net） }\end{array}$ & $\begin{array}{l}\text { 臨床研究中核病院である大阪大学を中心とした多施設共同臨床研究ネットワー } \\
\text { クである. 電子カルテに入力した情報から電子症例報告書の自動作成を可能と } \\
\text { し, 製薬企業が臨床試験や市販後調查の目的で各施設のデータを直接自社の } \\
\text { データベースに取り込むことができるシステム構築を目指している }\end{array}$ \\
\hline $\begin{array}{l}\text { 一般社団法人健康·医療・ } \\
\text { 教育情報評価推進機構 } \\
(\mathrm{HCEI})\end{array}$ & $\begin{array}{l}\text { HCEI では, } 2015 \text { 年夏より, 全国の多くの医療機関と連携をして電子カルテ由 } \\
\text { 来の各種情報を収集し, リアルワールドデータ株式会社 (RWD 社) の技術支援 } \\
\text { によってデータベース構築を行い, 研究機関や製薬企業等に対するデータセッ } \\
\text { トの提供 (二次利用) を開始している. } 2017 \text { 年 } 1 \text { 月時点で, 契約ベースでは } \\
1,270 \text { 万人規模の患者数となっている }{ }^{3738) .}\end{array}$ \\
\hline
\end{tabular}

ニングは，医療機関，製薬企業共に大きな負担が かかる業務の一つである，デー夕の質を落とすこ となくこの負担を軽減するために，これまでに電 子症例報告書や品質管理システム $(\mathrm{QMS})$, riskbased monitoring が導入されているが32)，これら に続く策として，EHRを原資料とした臨床試験 データの収集が試みられている。 EHR から直接 電子的にデー夕収集することで, より多くのデー 夕を少ない負担で入手可能となる。これまで症例 報告書の作成や原資料との整合性確認に費やして いた労力や費用を減らすことで，医療機関や製薬 企業は被験者対応等により一層注力することがで き, 円滑な試験の実施につながる.

海外では EHR システムと試験依頼者データ ベースとの統合による直接デー夕収集が盛んに試 みられている. 前述の Salford Lung Studyは EHR をデータソースとして活用した事例として みることもできる.この試験では病院および薬局 での医療デー夕から試験に必要なデー夕を直接収 集する EHR システムを用いた。これにより，試 験中に安全性情報をタイムリーに監視できたこと も大きいメリットである33). また, アストラゼネ 力社が世界 6 力国 30 万例を超える 2 型糖尿病患 者を対象に実施したCVD-REAL 試験では, 米国, スウェーデン，ノルウェー等の EHR データを用 いている。医療機関から保険会社への医療費申 請，プライマリーケアまたは病院，および各国の
登録研究よりデー夕を収集し, 糖尿病治療薬 SGLT2 阻害薬による治療後の心不全による入 院・総死亡のリスクを評価した ${ }^{34)}$ 。その他にも, EHR データが臨床試験結果への日常診療下での 情報追加や承認取得後の適応追加, 市販後試験な どに活用されている例もある。

本邦においても，EHR を用いたデー夕収集・利 活用の体制構築が進められている。代表的なもの を表 2 に示す.

このような $\mathrm{EHR}$ をデータソースとして活用し た臨床試験を日本で実施するには, インフラの構 築・整備が課題となる. 電子カルテの国内普及率 は 2006 年度までに病院・診療所の 6 割以上を目 標としていたが, 2014 年に至っても未だ $35 \%$ 程 度とのデータがある ${ }^{3940)}$. また, 電子カルテ間の 互換性等の面からも課題は多い.2017 年の医療 IT に関する経済協力開発機構 (OECD) の報告書 では，データガバナンスおよび技術・実用性の両 方で, 日本は調查対象 27 力国中最低と評価され ている現状がある ${ }^{41)}$.もう一つの課題として, 日 常診療で収集される EHR が臨床試験に必要なす べての情報を網羅することは難しく, 臨床試験特 有の電子症例報告書で収集するデータとの統合が 必要となる。 その場合, EHR システムベンダー は個人情報の取扱いを安全に保ちながら EHR シ ステムを依頼者のデータベースとつなぐためのシ ステム構築が必要となる。また，日本では電子力 
表 3 臨床試験の評価や診断への RWDの利活用場面と今後への期待

\begin{tabular}{|c|c|c|}
\hline キーワード & 事例·利活用場面 & 今後への期待 \\
\hline エンドポイント & $\begin{array}{l}\text { 患者の電子病理レポートを用いて, 機械学習等 } \\
\text { を利用したエンドポイントの判定が行われてい } \\
\text { る } \\
{ }^{43)} \text {. }\end{array}$ & $\begin{array}{l}\text { RWD は, 新たなエンドポイントの構築やコン } \\
\text { パニオン診断の精度向上に活用できると予想さ } \\
\text { れ, 個別化医療の推進に繋がる. }\end{array}$ \\
\hline バイオマーカー & $\begin{array}{l}\text { 認知症の血液バイオマーカーが利根町コホート } \\
\text { 研究で発見され, これにより新たな簡便なスク } \\
\text { リーニング法が開発された. さらに, より精度 } \\
\text { の高い結果を得るため } \mathrm{AI} \text { 技術の適用検討が進 } \\
\text { められている }{ }^{44)} .\end{array}$ & $\begin{array}{l}\text { バイオバンク・ジャパンやナショナルセン } \\
\text { ター・バイオバンクネットワーク, 東北メディ } \\
\text { カル・メガバンク等のバイオバンクの充実が, } \\
\text { 新たな診断法や治療法の開発に活用される. }\end{array}$ \\
\hline 画像デー夕 & $\begin{array}{l}\mathrm{AI} \text { 技術で, } 100 \text { 万枚以上の眼球スキャンデータ } \\
\text { を学習し, 視覚変性症例のパターンを分析する } \\
\text { ことで正確な診断を与えることができる年). } \\
\text { た, 肺がん組織の病理画像に対し, その画像デー } \\
\text { タから何千もの客観的特徵を特定し, そのサン } \\
\text { プルデータを評価するアルゴリズムの開発が進 } \\
\text { んでいる }{ }^{46)} .\end{array}$ & $\begin{array}{l}\text { 臨床試験で扱う機会が少ない画像データは, AI } \\
\text { 技術を駆使することで客観的な評価項目として } \\
\text { 利用可能になる. 加えて, 客観性を有する評価 } \\
\text { 項目を中央判定に利用すれば, 臨床試験の均一 } \\
\text { 化, 判定の明確化にも繋がり, 臨床試験の最適 } \\
\text { 化を促すことが可能になる. }\end{array}$ \\
\hline $\begin{array}{l}\text { ウェアラブル・セ } \\
\text { ンサー }\end{array}$ & $\begin{array}{l}\text { 腕時計型のウェアラブル端末では, 身体活動性 } \\
\text { の指標として治療効果の解析に活用したり, 睡 } \\
\text { 眠の評価, メラトニンリズムやひきこもりの解 } \\
\text { 析に活用したりすることが可能になっている. }\end{array}$ & $\begin{array}{l}\text { ウェアラブル端末, 体内および体外センサーを } \\
\text { 利活用するこで, 被験者の状態について, 膨 } \\
\text { 大でさまざまな種類の客観的データを収集する } \\
\text { ことが可能になり, 治験のエンドポイントとし } \\
\text { ての利活用が促進される. }\end{array}$ \\
\hline モバイル・アプリ & $\begin{array}{l}\text { Cardiogram 社の AI アプリは, 心拍数などの } \\
\text { データを解析し, } 24 \text { 時間心臓の健康状態を } \\
\text { チェックする. また, AiCure 社の AI アプリ } \\
\text { は, 服薬指導や管理, 有害事象の予測や報告を } \\
\text { 行う }\end{array}$ & $\begin{array}{l}\text { モバイルやアプリ等で日々発生するストリーミ } \\
\text { ングデータは, 臨床試験ではコンプライアンス } \\
\text { 向上等に活用でき, 一方で国民・患者の健康管 } \\
\text { 理に活用することで, 予防医療分野の活性化を } \\
\text { 促す可能性がある. }\end{array}$ \\
\hline
\end{tabular}

ルテの SS-MIX2 標準化ストレージの普及活動が 行われているものの普及率は低く ${ }^{42}$, システム構 築にはコストがかかることが予想される。 AMED も臨床研究エコシステムの構築として既 に取り組んでいるが，製薬業界全体でも検討すべ き課題である。

\section{4 臨床試験の評価や診断への活用}

IT 技術の進展によって多様な特性の RWD の 収集が可能になり, 急速な進歩を見せている人工 知能 (AI) 技術などの解析技術と上手く組み合わ せることで, 新しい臨床試験の評価や診断が確立 されつつある。臨床試験の評価や診断への RWD の利活用場面の例と今後への期待を表 3 にまとめ た。

RWD と eHealth や mHealth ${ }^{48)}$ といったデジタ ル技術は密接に関連している。携带端末, 患者モ
ニタリング端末, Personal Digital Assistantまた はその他のワイヤレス通信端末などのモバイル端 末を用いた eHealth として定義される mHealth は, 日常診療と臨床試験のどちらにおいても拡大 しており，お互いを切り離して語ることはできな い. これらはデータソースとしての側面と, 従来 の臨床試験で扱っていた数值やテキストデータを 超える特性のデータが得られるという側面があ る。例えば, Oracle 社が開発した InForm Medication Adherence Insights Cloud Service は, 被 験者が服用した薬片用量と服用時間を直接, 迅速 に確認でき, 投与量に関する意思決定の精度を改 善したり，医薬品の安全性を向上したりすること で試験の失敗リスクを低減することができ ${ }^{49)}$, こ れまでの臨床試験データにはなかったリアルタイ ム性という新しい特性のデータを獲得した事例と 
言えよう。他にもデジタル技術を使用した臨床試 験における RWDの有益な利活用の事例は多々あ り，アドヒアランス向上を目的としたデジタルピ ルやアプリの医療機器としての承認は既に現実と なっている。 今後, 製薬企業は, 医療機器として アプリやモバイル機器の開発を検討しながら, 医 薬品開発の最適化を図っていく時代となっていく だろう。

このような革新的な技術分野ではガイドライン のない領域が多く, 2018 年 11 月に意見募集され た「人工知能技術を利用した医用画像診断支援シ ステムに関する評価指標 (案) 」50)で, 性能評価お よび品質確保の方策の事前策定の推奨, 責任の所 在等の明確化が言及されているように, IT 技術 を生かした評価基準や診断基準を新規で構築する 際には，各自で設定根拠等の透明化を図り，信頼 性を担保する必要がある。また, 医療機器の開発 や画像解析などを臨床試験で適用するためには, データサイエンス分野や AI 分野に精通した人材 の確保・育成, データサイエンス分野に強みを持 つビジネスパートナーとの協働が重要であるが,

製薬企業は他産業に比べて遅れを取っている印象 がある。加えて，AI技術を駆使した医薬品開発 を推進するためには, 多様で大規模なデー夕が利 用できる環境が必要であり, オープンデー夕の増 加が望まれる。海外では Clinical Trial Data Sharing (CTDS) により臨床試験データのオープン ソース化が進み始めているものの, 本邦では CTDS の目立った動きはなく, 製薬企業が保有す るデー夕はまだ閉鎖的である。今後これらの課題 を解決し, 臨床試験のイノベーションを期待した い.

\section{5 開発戦略, 薬価・アクセス戦略への活用}

医薬品開発の各ステージにおける社内の意思決 定においてもRWDを活用する機会は増えてい る. 医薬品開発のコスト高騰や疾患のフラグメン ト化が進む中で開発計画やポートフォリオを検討 するには, 適切な市場規模の見積もりは製薬企業 にとって重要な課題である。これまでも処方箋 データ分析やマーケットリサーチは行われていた が, 対象疾患のフラグメント化で困難さが増し,
薬剂疫学 Jpn J Pharmacoepidemiol, 24(1) Jan 2019：25

患者レベルの RWD を用いた精度の高い推定が必 要となってくる. また, 開発計画で重要となるア ンメットニーズの掘り起こしにおいても, RWD 活用の機会がある。これまではアドバイザリー ボード等により医師の意見集約を行うことが多 かったが，患者中心の開発が広まる中で患者本人 の声を拾うことも重要となる．患者団体だけでな くインターネットコミュニティを活用した取組み が始まっており，このような RWDの医薬品開発 への活用も増えていくだろう。

海外ではPayer の薬価や保険償還に対する評 価に以前から RWEが活用されている。近年で は, 製薬企業と Payer 間で締結されるrisksharing agreements（RSA）において, 長期追跡 が必要なアウトカムの収集が必要となる場合で RWE を活用できる ${ }^{5152)}$. 日本の条件付き早期承 認制度での承認後のデー夕提出も, このような RWEの活用が期待される. 本邦の規制当局の意 思決定では, 条件付き早期承認制度の対象品目の 条件に合致するような薬剤は早期の開発段階から の RWE 活用戦略が重要である。それ以外の薬剤 でも, 申請データパッケージとしての外部対照等 は敷居が高いが，これまでも臨床試験結果の解釈 や一般化可能性の評価のために, 論文等の公表 データがリファレンスとして使われてきた。

RWD の特に二次利用データが豊富かつ気軽に使 えるようになれば, 公表論文だけに頼ることなく, より目的に合った精度の高いリファレンスデータ を自ら作ることができる。これまで紹介した活用 場面を含めて, RWD・RWEの医薬品開発への活 用を図 1 にまとめる.

アンメットニーズが高く革新的な薬剤は 1 日も 早い患者へのアクセスが望まれるが, 有效性・安 全性データが不十分な薬荗に対して, 上述の RSAのように国と企業がどのように合意してリ スクを取るかが課題である。最終的には，革新的 な薬剤を早く患者に届けるべネフィットとリスク のバランスの評価の話となる。無作為化比較検証 試験データがないときに, 規制当局にとっては承 認後に効果の欠落や安全性の問題などが見つかる リスクが増す。そのリスクを最小化するために 


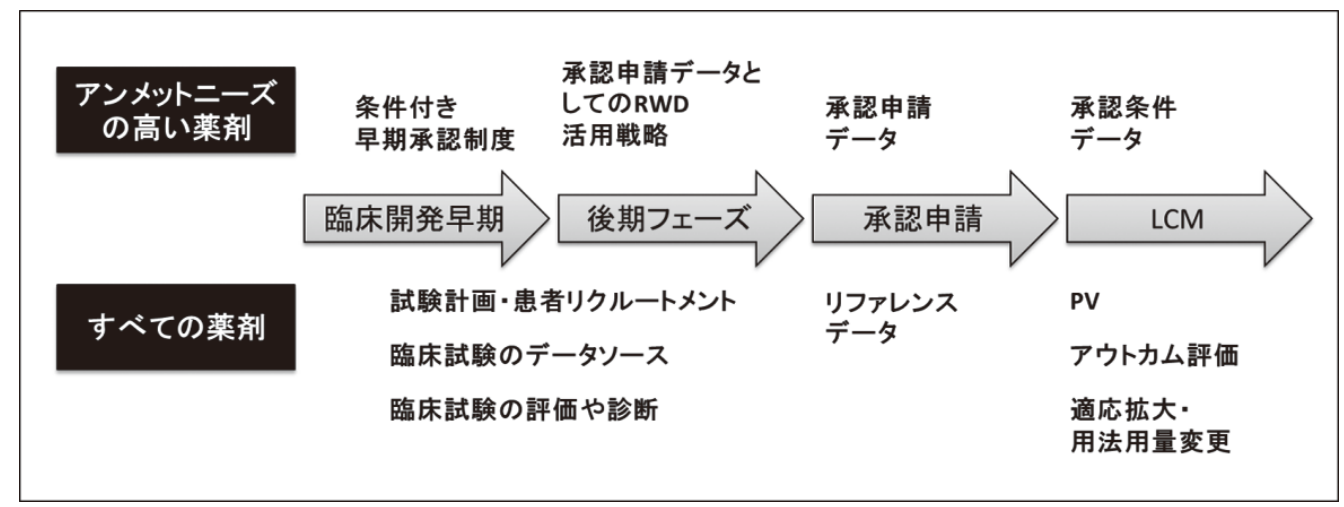

図 1 医薬品開発における RWD・RWE の活用場面

LCM : Life Cycle Management, PV : Pharmacovigilance

RWE は役に立つ. 成功報酬型の支払いなど今後 予想される多様な医療保険制度の下で RWE は生 きてくるだろう，RWDを単なるデータ活用とし てではなく, 新しい臨床開発, 市販後監視活動, 医療保険制度の枠組みと共に考えるべきである。 また，各国でRWDの活用が進む中で，国内の RWD 利用に関する規制環境が整わなければ，国 際共同開発の中で RWD を利用した臨床試験に日 本が参加し難い，RWE 創出のための日本への投 資が十分にされないなど, 国際競争力の低下が起 こりうるだろう。

\section{3. おわりに}

これまで述べてきたように，医薬品開発におい ても RWDの活用によりさまざまな効用が期待で きる.この 10 年ほどで, デー夕収集・視覚化・画 像処理・機械学習のすべてのプロセスを通じて, 計算機性能の向上, アルゴリズムの開発, グロー バル ICT ネットワーキング等は, あらゆるユー ザーにとって実用化可能なレベルに充足されてき た。それにもかかわらず, 医薬品産業では RWD 活用が他産業と比べて, また諸外国と比べて遅 滞53) しているとしたら，それはいったい何故であ ろうか. 本邦では, 医療データのほとんどは提供 者である患者個々の診療を最適化するためにのみ 収集され，第三者の利潤取得のために転用される べきものではないと考えるからであろうか. ある
いは製薬企業の開発部門やその管理部門が，治験 と呼ばれる実験的研究の呪縛に陥り, 個人デー夕 や情報を企業間競合や先発権の占有のために秘匿 することを是とする時代が長く続いたからであろ うか. 物事を根源から考えることが苦手な我々 は, 再び外部から急激かつ強力な「意識改革」の 必要性を迫られている。

「意識改革」は, ステイクホルダの一部が行うだ けでは意味がない. RWD 活用に問題解決型の行 政指導は効果的でない. 発生した問題の原因を追 究し, パーツごとに補修作業を施しても拡張型の プロジェクトは成功しない. 既存のローカルデー タベースやバイオバンクをリンクして構築したプ ラットフォームが, 海外のプラットフォームとの 連携やオープン・アクセスが可能となるとは思え ない. 先ずは, 各ステイクホルダにとっての本邦 の統合プラットフォームのあるべき姿を踏まえた 上で, 二次利用時の品質管理, 要配慮個人情報, さらには欧州一般保護指針 $(\mathrm{GDPR})^{54)}$ 等の海外規 制への対応など議論すべきであろう，GCP リノ ベーションを初めとしてさまざまな医薬品開発に 関する規制課題が组上に上がっている。今一度, RWD は誰のために活用すべきかを考え, 産官学 すべてのステイクホルダが既存の組織・機能体制 の枠を超えて，連携すべき時が来たように考える.

バイオバンク, DPC, Electronic Medical Record, 疫学コホートデータベース, レジストリ保 
有データ, CTDS 等々は，いずれも患者記録に他 ならない。これらのデータが統合または連結可能 となった低負担で相互アクセス可能なプラット フォームが実現された時, 製薬企業の求める臨床 試験・臨床研究の実施可能性や外的妥当性の評価, ヒストリカル・コントロール, バイオマーカー戦 略による開発プログラム等への活用, 並びに医療 機関の求める $\mathrm{AI}$ 診断・治療, テキストマイニン グ，デジタルヘルス，在宅医療実現等への活用に とどまらず，精密医療による個別化医療やリアル タイムな患者ニーズのトラッキングなどが促進さ れ，患者・社会に対するベネフィットを最大化で きるであろう。また，プラットフォームの運用に 必要なコス卜負担は, 個々の製薬会社, 医療機関, 国公立機関の短期的な負担に依存せず，広く民間 投資が得られることも期待される ${ }^{55)}$.

\section{謝辞}

本稿は日本製薬工業協会 医薬品評価委員会 臨床 評価部会の 2017 年度部会内部資料「医療ビッグデー 夕の治験等への利活用」を参考にしており, 資料を共 に作成した谷口裕子氏（ゼリア新薬工業株式会社）, 前田章太郎氏 (杏林製薬株式会社), 松尾大輔氏 (小野 薬品工業株式会社) およびタスクフォースメンバーに 深謝の意を表する。 また, 本稿にご助言を戴いた臨床 評価部会委員に感謝する。

\section{文献}

1) International Council for Harmonisation of Technical Requirements for Pharmaceuticals for Human Use. ICH Reflection on "GCP Renovation” : Modernization of ICH E8 and Subsequent Renovation of ICH E6. 2017. [https://www. ich. org/fileadmin/ Public_Web_Site/ICH_Products/GCP_Renovation/ ICH_Reflection_paper_GCP_Renovation_Jan_2017_ Final.pdf (accessed 2018-11-01)]

2) 厚生労働省. 医薬品の条件付き早期承認制度の実施 について，厚生労働省医薬・生活衛生局医薬品審査 管理課長. (薬生薬審発 1020 第 1 号 平成 29 年 10 月 20 日).

3）厚生労働省. 医薬品の製造販売後の調査及び試験の 実施の基準に関する省令等の一部を改正する省令の 公布について，厚生労㗢省医薬·生活衛生局長.（薬 生発 1026 第 1 号 平成 29 年 10 月 26 日).

4）日本医療研究開発機構. 医薬品等規制調和・評価研 究事業. 患者レジストリーデータを用い，臨床開発 の効率化を目指すレギュラトリーサイエンス研究.
薬剂疫学 Jpn J Pharmacoepidemiol, 24(1) Jan 2019：27

平成 28 年度研究成果報告書. 2017. [https:// www.amed.go.jp/content/files/jp/houkoku_h28/ 0502053/h28_022.pdf (accessed 2018-11-01)]

5）首相官邸. 健康 ·医療戦略推進本部. 健康 - 医療戦 略(平成 26 年閣議決定, 平成 29 年一部変更)。 2017. [https://www.kantei.go.jp/jp/singi/kenkouiryou/ suisin/ketteisiryou/kakugi/170217senryaku.pdf (accessed 2018-11-01) ]

6）医療分野の研究開発に資するための匿名加工医療情 報に関する法律（平成二十九年法律第二十八号）.

7）厚生労働省 社会保険診療報酬支払基金 国民健康保 険中央会. 国民の健康確保のためのビッグデータ活 用推進に関するデータヘルス改革推進計画. 2017. [http://www. mhlw. go. jp/file/05-Shingikai12601000-Seisakutoukatsukan-Sanjikanshitsu_Sha kaihoshoutantou/0000173049.pdf (accessed 201811-01) ]

8) 21st Century Cures Act, H.R. 34, 114 $4^{\text {th }}$ Congress. 2016. [https://www. congress. gov/bill/114thcongress/house-bill/34/text (accessed 2018-1101)]

9) U.S. Department of Health and Human Services Food and Drug Administration. Use of Real-World Evidence to Support Regulatory Decision-Making for Medical Devices. [https://www.fda.gov/down loads/medicaldevices/deviceregulationandgui dance/guidancedocuments/ucm513027.pdf (accessed 2018-11-01)]

10) Innovative Medicines Initiative (IMI) GetREAL project. [http://www.imi-getreal.eu/(accessed 2018-11-01)]

11) Berger ML, Sox H, Willke RJ, et al. Good practices for real-world data studies of treatment and/or comparative effectiveness : recommendations from the Joint ISPOR-ISPE Special Task Force on realworld evidence in health care decision making. Value in Health 2017 ; 20 (8) : 1003-8.

12) Silverman B. Roche's External Control Arms Show What Real-World Evidence Can Look Like In Practice. Pink Sheet. 2018. [https://pink. phar maintelligence.informa.com/PS123286/RochesExternal-Control-Arms-Show-What-RealWorldEvidence-Can-Look-Like-In-Practice (accessed 2018-11-01) ]

13) McKinsey \& Company. Real-world evidence : Driving a new drug development paradigm in oncology. [https://www.mckinsey.com/ /media/mckinsey/ industries/pharmaceuticals\%20and\%20medical $\% 20$ products/our\%20insights/real\%20world\%20 evidence $\% 20$ driving $\% 20$ a $\% 20$ new $\% 20$ drug $\% 20$ development\%20paradigm\%20in\%20oncology/realworld-evidence-driving-a-new-drug-developmentparadigm-in-oncology. ashx (accessed 2018-11-01)]

14）日本製薬工業協会 医薬品評価委員会 データサイエ 
ンス部会 2017 年度タスクフォース 5. Pragmatic Trials のススメ. 2018. [http://www.jpma.or.jp/ medicine/shinyaku/tiken/allotment/pdf/pragmat ic_trial_final_2.pdf (accessed 2018-11-01)]

15）グラクソ・スミスクライン株式会社. プレスリリー ス 2017 年 5 月 25 日. [http://jp.gsk.com/jp/me $\mathrm{dia} /$ press-releases/2017/20170525-sls-asthma/ (accessed 2018-11-01)]

16) Duke University, The Duke-Margolis Center for Health Policy. Enhancing the Application of RealWorld Evidence in Regulatory Decision-Making. 2016. [https://healthpolicy.duke.edu/sites/default/ files/atoms/files/slides_3_3_16\%20-\%20Part\%201. pdf (accessed 2018-11-01)]

17) Galson S, Simon G. Real-World Evidence to Guide the Approval and Use of New Treatments. National Academy of Medicine. 2016. [https://nam.edu/wpcontent/uploads/2016/10/Real-World-Evidence-toGuide-the-Approval-and-Use-of-New-Treatments. pdf (accessed 2018-11-01) ]

18) Clinical Informatics News. Using Real World Data to Enhance Clinical Trials. 2017. [http://www. clini calinformaticsnews.com/2017/1/13/using-realworld-data-to-enhance-clinical-trials.aspx (accessed 2018-11-01) ]

19) Bakerly ND, Woodcock A, New JP, et al. The Salford Lung Study protocol: a pragmatic, randomised phase III real-world effectiveness trial in chronic obstructive pulmonary disease. Respir Res 2015 ; $16: 101$.

20）今井志乃ぶ. 北欧におけるビッグデータの活用. Jpn J Drug Inform $2014 ； 16$ (2) : N29-N32.

21) Fröbert $O$, Lagerqvist $B$, Gudnason $T$, et al. Thrombus Aspiration in ST-Elevation myocardial infarction in Scandinavia (TASTE trial). A multicenter, prospective, randomized, controlled clinical registry trial based on the Swedish angiography and angioplasty registry (SCAAR) platform. Study design and rationale. Am Heart J 2010 ; 160 (6) : 1042-8.

22) Alemayehu D, Berger ML. Big data : transforming drug development and health policy decision making. Health Serv Outcomes Res Methodl 2016 ; 16 (3) : 92-102.

23) Duke University, The Duke-Margolis Center for Health Policy. Characterizing RWD Quality and Relevancy for Regulatory Purposes. 2018. [https:// healthpolicy.duke.edu/sites/default/files/atoms/ files/characterizing_rwd.pdf (accessed 2018-1101) ]

24) Huang GD, Bill J, Johnston McKee K, et al. Clinical trials recruitment planning: A proposed framework from the Clinical Trials Transformation Initiative. Contemp Clin Trials 2018 ; 66 : 74-9.
25) Kimko HC, Peck CC. Clinical Trial Simulations : Applications and Trends. Springer-Verlag New York, 2011.

26) Kimko H, Lee K. Improving Realism in Clinical Trial Simulations via Real-World Data. CPT Pharmacometrics Syst Pharmacol 2017 ; 6 (11) : 727-9.

27) Pobiruchin M, Bochum S, Martens UM, Kieser M, Schramm W. A method for using real world data in breast cancer modeling. J Biomed Inform 2016 ; 60 : 385-94.

28) Wilke T, Groth A, Mueller S, et al. How to use pharmacy claims data to measure patient nonadherence? The example of oral diabetics in therapy of type 2 diabetes mellitus. Eur J Health Econ 2013 ; 14 (3) : 551-68.

29）日本製薬工業協会 医薬品評価委員会 臨床評価部会 タスクフォース 3 . 患者の声を活かした医薬品開 発一製薬企業による Patient Centricity一. 2018. [http://www.jpma.or.jp/medicine/shinyaku/ tiken/allotment/pdf/patient_centricity.pdf (accessed 2018-11-01) ]

30) 国立がん研究センター東病院. SCRUM-Japan. [http://www.scrum-japan.ncc.go.jp/ (accessed 2018-11-01)]

31) ELLIGO HEALTH RESEARCH. [https://www. elligohealthresearch.com/]

32) Uren SC, Kirkman MB, Dalton BS, Zalcberg JR. Reducing clinical trial monitoring resource allocation and costs through remote access to electronic medical records. J Oncol Pract $2013 ; 9$ (1) : e13-6.

33) Collier S, Harvey C, Brewster J, et al. Monitoring safety in a phase III real-world effectiveness trial : use of novel methodology in the Salford Lung Study. Pharmacoepidemiol Drug Saf 2017 ; 26 (3) : 344-52.

34）アストラゼネカ株式会社. 広報資料 2017 年 3 月 21 日. [https://www.astrazeneca.co.jp/media/pressreleases1/2017/20170321.html (accessed 2018-1101) ]

35）吉原博幸. 千年カルテプロジェクト：本格的日本版 EHR と医療データの 2 次利用に向けて. 情報管理 $2018 ； 60$ (11) : 767-78.

36）日本製薬工業協会 医薬産業政策研究所. 医療健康 分野のビッグデータ活用研究会報告書 Vol. 3. 2018. [http://www.jpma.or.jp/opir/journal/pdf/ journal_003.pdf (accessed 2018-11-01)]

37）川上浩司. 医療, 社会の変化に対応して, リアルワー ルドデータが切り拓く新たな薬剤疫学. 薬剂疫学 $2017 ; 22$ (1) : 37-43

38) 日本薬剂疫学会薬剤疫学とデータベースタスク フォース. 日本における臨床疫学・薬剤疫学に応用 可能なデータベース調査. 2017. [http://www. jspe.jp/committee/020/0210/(accessed 2018-1101)]

39）厚生労働省. 医療施設調査. [http://www.mhlw. 
薬剂疫学 Jpn J Pharmacoepidemiol, 24(1) Jan 2019：29

go.jp/toukei/list/79-1.html (accessed 2018-11-01)] 40）一般社団法人保険医療福祉情報システム工業会 (JAHIS)，医療情報システム（オーダエントリ・電 子カルテシステム）導入調查報告 2017 年調査. [https://www.jahis.jp/action/id=57?contents_ type=23 (accessed 2018-11-01)]

41) The Organisation for Economic Co-operation and Development (OECD). OECD Reviews of Health Care Quality : Japan 2015. [https://www.oecd-ili brary.org/social-issues-migration-health/oecd-re views-of-health-care-quality-japan-2015_9789264225 817-en (accessed 2018-11-01)]

42）国立研究開発法人科学技術振興機構研究開発戦略セ ンター。 [調査報告書] 医療・介護データ活用のため の情報科学と社会基盤. 2016. [https://www.jst. go.jp/crds/pdf/2016/RR/CRDS-FY2016-RR-03.pdf (accessed 2018-11-01) ]

43) Goulart BHL, Silgard E, Baik CS, et al. Validation of natural language processing (NLP) for automated ascertainment of EGFR and ALK tests in SEER cases of non-small cell lung cancer (NSCLC).J Clin Oncol 2017 ; 35 (15) : 6528.

44）公益財団法人ヒューマンサイエンス振興財団. 医療 分野におけるビッグデータ並びに ICT ・ AI の利活 用の最新動向. 2017. [http://www.jhsf.or.jp/pa per/report/report_201604.pdf (accessed 2018-1101) ]

45) MESM. AI, big data and clinical trials-thoughts on the collaboration between Google's DeepMind and Moorfields Eye Hospital. 2016. [https://www. mesm.com/blog/ai-big-data-and-clinical-trialsthoughts-on-the-collaboration-between-google-sdeepmind-and-moorfields-eye-hospital (accessed 2018-11-01) ]

46) General Electric Company. Big Data, Analytics \& Artificial Intelligence-The Future of Health Care is Here-. 2016. [http://newsroom. gehealthcare. com/wp-content/uploads/2016/12/GE-HealthcareWhite-Paper_FINAL.pdf (accessed 2018-11-01) ]

47） ITiger. 医療・ヘルスケア業界における AI 活用事 例 14 選. 2017. [http://itiger.jp/case/721.html (accessed 2018-11-01) ]

48) World Health Organization. Global Observatory for
eHealth series (Volume 3). 2011. [http://www.who. int/goe/publications/ehealth_series_vol3/en/(accessed 2018-11-01) ]

49) Henderson L. The Use of mHealth in Clinical Trials. Applied Clinical Trials. 2015. [http://www. appliedclinicaltrialsonline.com/use-mhealth-clinicaltrials (accessed 2018-11-01) ]

50）厚生労働省. 人工知能技術を利用した医用画像診断 支援システムに関する評価指標(案)．2018. [http:// search.e-gov.go.jp/servlet/PcmFileDownload?seq No=0000179718 (accessed 2018-11-01) ]

51) Gonçalves FR, Santos S, Silva C, Sousa G. Risksharing agreements, present and future. Ecancermedicalscience $2018 ; 12: 823$.

52) Garrison LP Jr, Towse A, Briggs A, et al. Performance-based risk-sharing arrangements-good practices for design, implementation, and evaluation : report of the ISPOR good practices for performance-based risk-sharing arrangements task force. Value Health 2013 ； 16（5）: 703-19.

53）公益社団法人経済同友会. データ利活用基盤の構築 を急げ—QOL を向上させるデータヘルスに関する 中間提言. 2018. [https://www.doyukai.or.jp/pol icyproposals/uploads/docs/180525a.pdf (accessed 2018-11-01)]

54) The European Parliament and the Council of the European Union. Regulation (EU) 2016/679 of the European Parliament and of the Council of 27 April 2016 on the protection of natural persons with regard to the processing of personal data and on the free movement of such data, and repealing Directive 95/46/EC (General Data Protection Regulation) (Text with EEA relevance), OJ L 119, 4.5.2016, p. 1-88 (BG, ES, CS, DA, DE, ET, EL, EN, FR, GA, HR, IT, LV, LT, HU, MT, NL, PL, PT, RO, SK, SL, FI, SV). [http://data. europa. eu/eli/reg/ 2016/679/oj (accessed 2018-11-01)]

55）経済産業省ヘルスケア産業課. 健康・医療情報の利 活用に向けた民間投資の促進に関する研究会（へ ルスケア IT 研究会) 中間取りまとめ. 2018. [https://www.meti.go.jp/report/whitepaper/data/ pdf/20180427001_01.pdf (accessed 2018-11-01)] 
Special Issue on "Progress and Challenge of Drug Development and Pharmacovigilance Through Utilization of Real World Data"

\title{
3. Utilizing Real World Data in Drug Development -Expectations from Pharmaceutical Companies-
}

\author{
Kanae TOGO ${ }^{* 1, * 2}$, Shinya KAWAMATSU ${ }^{* 1, * 3}$, Ryo KIGUCHI ${ }^{* 1, * 4}$, Yasuhiko IMAI*1,*5 \\ ${ }^{* 1}$ Clinical Evaluation Expert Committee, Drug Evaluation Committee, \\ Japan Pharmaceutical Manufacturers Association, Japan \\ *2 Pfizer Japan Inc., Japan \\ *3 GlaxoSmithKline K.K., Japan \\ *4 Shionogi \& Co., Ltd., Japan \\ ${ }^{* 5}$ Bristol-Myers Squibb K.K., Japan
}

\section{$\langle$ Abstract〉}

The source of clinical evidence in drug development has been limited to be generated from clinical trials for many years. However, the evidence generation should be extended to Real World Data (RWD), which will play a key role anywhere. The ICH GCP renovation recommends selecting from a variety of clinical trial designs and data sources choices where innovative new drugs will be provided to patients as an earlier approval of the new drug application. In the early-stage approval system of the Ministry of Health of Labor and Welfare and the revision of GPSP in Japan, it is clearly stated that medical databases and patients' registry will be available. In this manuscript, we summarize the following cases of the utilizing RWD in drug development ; (1) submitting data for a new drug application, (2) planning of clinical trials and patients' recruitment for clinical trials, (3) collecting clinical trial data using Electronic Health Record as data source, (4) assessing clinical outcomes and diagnosis, (5) developing strategies of drug development, drug pricing and access. Although there are many challenges in each application and the improvement in the infrastructure and regulatory environment is desired, we hope the progress of RWD use in the practice of drug development without waiting for that.

(Jpn J Pharmacoepidemiol 2019; 24(1): 19-30)

Keywords: real world data, real world evidence 